\title{
Influence of blood serum selenium on udder health in dairy cows
}

\author{
doi: $10.15567 /$ mljekarstvo.2014.0305 \\ Ivana Davidov ${ }^{1}$, Marko R. Cincović ${ }^{*}$, Branislava Belić ${ }^{1}$, Anka Popović Vranješ ${ }^{1}$, \\ Radovan Pejanović ${ }^{\prime}$, Radojica Đoković ${ }^{2}$, Zoran Ristić ${ }^{3}$, Maja Došenović ${ }^{1}$ \\ ${ }^{1}$ University of Novi Sad, Faculty of Agriculture, D. Obradovića 8, \\ 21000 Novi Sad, Vojvodina, Serbia \\ ${ }^{2}$ University of Kragujevac, Faculty of Agronomy Čačak, Cara Dušana 34, \\ 32000 Čačak, Serbia \\ ${ }^{3}$ University of Novi Sad, Faculty of Science, D. Obradovića 3, \\ 21000 Novi Sad, Vojvodina, Serbia \\ Received - Prispjelo: 16.12.2013. \\ Accepted - Prihvaćeno: 15.07.2014.
}

\begin{abstract}
The aim of this study was to determine the effect of selenium concentration in early lactation on mammary gland health and histological characteristics of the udder. The experiment included 30 high-yielding Holstein-Friesian cows. Selenium concentrations in blood and milk serum, and the average somatic cell count in the first and sixth months of lactation were analyzed. After exclusion of the experimental cows from the herd, histological characteristics of the udder were examined (the degree of leukocyte infiltration and the number of granulomas in the parenchyma). The mean selenium concentration in the blood serum was $0.62 \pm 0.11 \mathrm{mmol} / \mathrm{L}$ and that in the milk serum was $0.12 \pm 0.07 \mathrm{mmol} / \mathrm{L}$. Optimal blood levels of selenium were found in 19 cows and suboptimal levels in 11 cows. A significant negative correlation was observed between blood and milk selenium concentrations and somatic cell count in early and mid lactation. There was no relationship between blood selenium concentration, milk selenium concentration and the amount of milk produced. Selenium-deficient cows had a significantly higher milk somatic cell count in early and mid lactation and significantly lower levels of selenium in milk. Upon histological analysis, 120 samples of individual quarters of the udder were grouped according to the degree of leukocyte infiltration and number of granulomas. Results showed that an increase in the degree of leukocyte infiltration and number of granulomas leads to an increase in the proportion of quarters from selenium-deficient cows and a decline in the percentage of quarters from cows exhibiting normal blood selenium concentrations. Selenium has a significant impact on udder health. Changes caused by selenium deficiency occur due to marked inflammation process in the mammary gland.
\end{abstract}

Key words: dairy cows, selenium, udder histology, inflammation

\section{Introduction}

Trace elements have essential importance in maintaining udder health of cows. Sordillo et al. (1997) argue that there are two mechanisms by which micronutrients help to preserve the health of the mammary gland: 1) enhancing the activity of the first line of defense against bacterial penetration and increasing the defensive ability of epithelial cells to combat microorganisms that enter the mammary gland tissue and 2) enhancing the phagocytic mechanism at the site of bacterial penetration into the mammary gland. Zinc plays an important role in the proper function of the first mechanism. It affects the degree of keratinization of the teat canal, 
thereby protecting the udder against bacterial penetration after milking (Davidov et al., 2013). The second mechanism is related to the effect of selenium in the body. Selenium acts as a cellular antioxidant in the cell cytoplasm, by preventing cell damage due to peroxidase, and plays a major role in the function of the immune response (Miller et al., 1993). Parturition and early lactation lead to a weakened immune system and a subsequent increase in the risk of infection in dairy cows (Mallard et al., 1998). Miller et al. (1995) found that blood selenium concentrations decrease at parturition. Uncontrolled peroxide is highly damaging to healthy cells and healthy tissue of the mammary gland (Kommisrud et al., 2005). Selenium is essential in helping leukocytes: reduce the formation of peroxides, translate them into safe substances and, then, destroy phagocytized pathogens (Larsen, 1993; Finch and Turner, 1996, Smith et al. 1997, McKenzie et al., 1998).

We hypothesized that selenium deficiency in early lactation can affect mammary gland health in cows. The aim of this study was to determine the effect of selenium concentration in early lactation on mammary gland health: milk production, milk serum selenium concentration, somatic cell count and histological characteristics of the udder.

\section{Material and methods}

\section{Animals}

The experiment included 30 high-producing dairy Holstein-Friesian cows raised under farm conditions. The cows had similar body condition scores. They were in their third or fourth lactation and gave approximately the same amount of milk in the previous lactation (7000 liters).

\section{Blood analysis}

Blood was taken during the first month of lactation (25-30 days) by v.coccygea to determine selenium concentration. Blood sera were further analyzed by atomic absorption spectrometry (AAS) on a Perkin Elmer Elan 6100 ICPMS, Massachusetts, USA. Selenium concentration was determined using the method described by Maas et al. (1992).

\section{Milk analysis}

Milk samples were taken at the time of blood sampling. Somatic cell count (SCC) was determined in bulk milk samples from every quarter using MILKOSCAN appliances. Milk serum was separated for the purpose of measuring selenium concentration and further analyzed by atomic absorption spectrometry on a Perkin Elmer Elan 6100 ICPMS, Massachusetts, USA. The methodology was the same as for the blood serum.

\section{Histological analysis of the udder}

The udders of 30 Holstein - Friesian cows (120 quarters) were taken for histological examination after cow exclusion from the herd. Analysis of histological preparations was performed on a Leica microscope. A quantitative method described by Mayer and Klein (1961) was used to assess the degree of damage to the alveolar epithelium, alveolar lumens and intra-alveolar stroma. Changes were identified under a light microscope magnification of 10x and 40x. The degree of leukocyte infiltration was determined based on the presence of certain inflammatory cells in the corresponding field of view, as follows: leukocyte infiltration of $0 \%$ to $25 \%=$ presence of several neutophil granulocytes and lymphocytes; leukocyte infiltration of $25.1 \%$ to $50 \%$ $=$ presence of a significant number of neutrophils, lymphocytes and rare macrophages; leukocyte infiltration of $50.1 \%$ to $75 \%=$ massive infiltration of lymphocytes, a significant number of macrophages and rare eosinophils; leukocyte infiltration of $75.1 \%$ to $100 \%=$ massive infiltration of lymphocytes and macrophages with a few plasma cells and eosinophils. Inflammation processes include granulomas with or without hypertrophy/hyperplasia of the connective tissue of the glandular part of the udder.

\section{Statistical analysis}

As part of descriptive statistics, data are presented as mean values \pm SD. The second step involved the assessment of the correlation between blood and milk serum selenium concentrations and other mammary gland health parameters. Cows were allocated to two groups based on blood selenium levels: cows having optimal selenium concentrations $(>0.6 \mathrm{mmol} / \mathrm{L})$ and selenium-deficient cows $(<0.6 \mathrm{mmol} / \mathrm{L})$. Differences in udder health between cows exhibiting optimal and suboptimal 
levels of selenium in the blood serum in early lactation were determined by examining differences in milk production, milk selenium concentration and somatic cell count in early and mid lactation using Student's t-test. The effect of selenium on the morphological characteristics of the udder was analyzed by the Cochran-Armitage test for trend through differences in the proportion of quarters exhibiting different degrees of leukocyte infiltration and different numbers of granulomas. The statistics package Statgraphics Centurion was used for these purposes.

\section{Results and discussion}

The average selenium concentration in the blood serum was $0.62 \pm 0.11 \mathrm{mmol} / \mathrm{L}$ and that in the milk serum was $0.12 \pm 0.07 \mathrm{mmol} / \mathrm{L}$. Optimal blood selenium concentrations were found in 19 cows and suboptimal concentrations in 11 cows. Udder health parameters indicated that the average milk production per cow was $25.14 \pm 3.3$ liters/day and the average somatic cell count in the first and sixth months of lactation was $375 \pm 84$
$(000 / \mathrm{mL})$ and $286 \pm 69(000 / \mathrm{mL})$, respectively. The data are shown in Table 1.

Histological characteristics of the udder are outlined in Figures 1, 2 and 3. Figure 1 shows a healthy parenchymatous tissue (a) and parenchymal tissues infiltrated by immune cells (b, c). Figure 2 illustrates acinar atrophy in the mammary gland and proliferation of connective tissue, indicating the initiation of the inflammation process. Further development of the inflammation process is indicated by the formation of granulomas, as presented in Figure 3. A leukocyte infiltration rate of $0-25 \%$ was determined in 45 of the 120 udder quarters, and that of 75.1 to $100 \%$ in 12 . As regards the presence of the inflammation processes, 57 of the 120 quarters were found to have 1-3 granulomas in the visual field under low magnification, and more than 5 granulomas were detected in 19 quarters. The data are shown in Table 1.

Blood selenium concentration correlated negatively with milk somatic cell count in early and mid lactation. The relationship between blood selenium concentration and the concentration of micronutrients in milk was not supported.

Table 1. Descriptive statistics for the test parameters

\begin{tabular}{|c|c|c|}
\hline Parameter & & Value \\
\hline Blood selenium $(\mu \mathrm{mol} / \mathrm{L})$ & & $0.62 \pm 0.11$ \\
\hline No. of cows with optimal/suboptimal blood selenium concentration & & $19 / 11$ \\
\hline Milk selenium $(\mu \mathrm{mol} / \mathrm{L})$ & & $0.12 \pm 0.07$ \\
\hline Milk yield (liters/day/cow) & & $25.14 \pm 3.3$ \\
\hline SCC in the first month of lactation $(000 / \mathrm{mL})$ & & $375 \pm 84$ \\
\hline SCC in the sixth month of lactation $(000 / \mathrm{mL})$ & & $289 \pm 69$ \\
\hline \multirow{4}{*}{$\begin{array}{l}\text { Number of udder quarters exhibiting different levels (\%) of leukocyte } \\
\text { infiltration in the tissue }\end{array}$} & $0-25 \%$ & 45 \\
\hline & $25.1-50 \%$ & 35 \\
\hline & $50.1-75 \%$ & 28 \\
\hline & $75.1-100 \%$ & 12 \\
\hline \multirow{4}{*}{$\begin{array}{l}\text { Number of udder quarters having different numbers of granulomas in } \\
\text { the tissue }\end{array}$} & 0 & 14 \\
\hline & $1-3$ & 57 \\
\hline & $4-5$ & 30 \\
\hline & $>5$ & 19 \\
\hline
\end{tabular}

Table 2. Correlation coefficient between blood and milk selenium, SCC and milk production

$$
\text { Milk Se Milk yield (L/cow/day) SCC first month } \quad \text { SCC sixth month }
$$

\begin{tabular}{lllll}
\hline Blood Se & 0.33 & 0.22 & $-0.71^{* *}$ & $-0.69^{* *}$ \\
\hline Milk Se & & 0.31 & $-0.65^{* *}$ & $-0.7^{* *}$ \\
\hline${ }^{* *} \mathrm{p}<0.01$ & & &
\end{tabular}




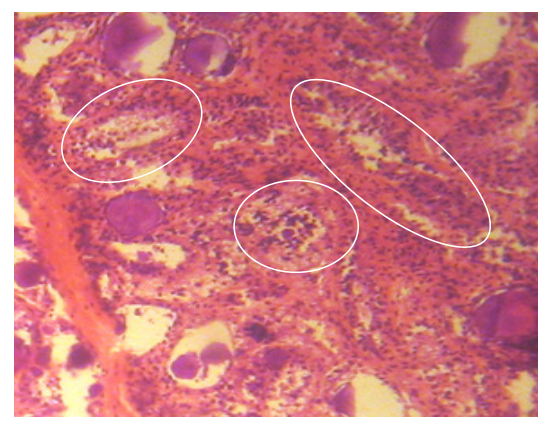

a)

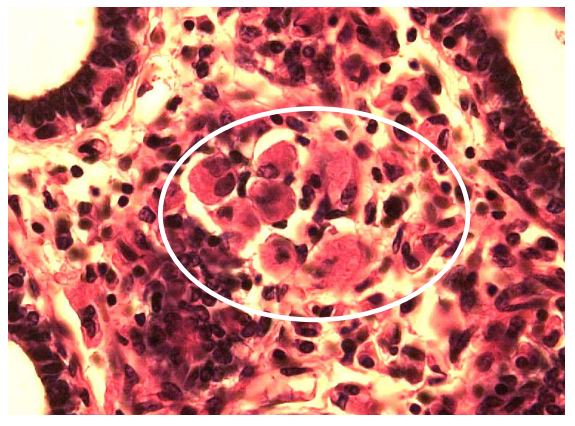

b)

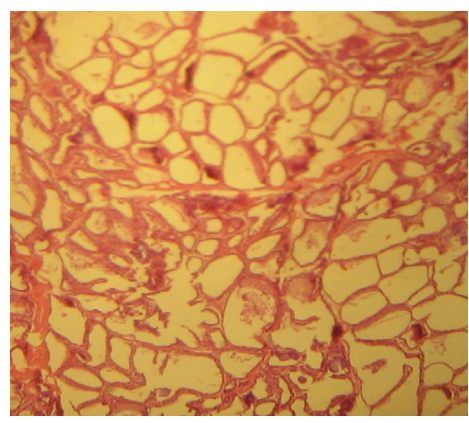

c)

Figure la-c. Leukocyte and maccrophage infiltration of udder parenchyma (rounded, a and b) and healthy tissue $(c)$

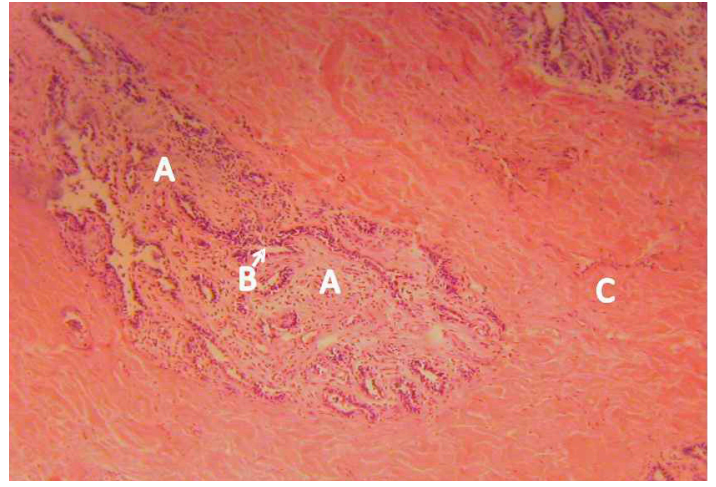

a)

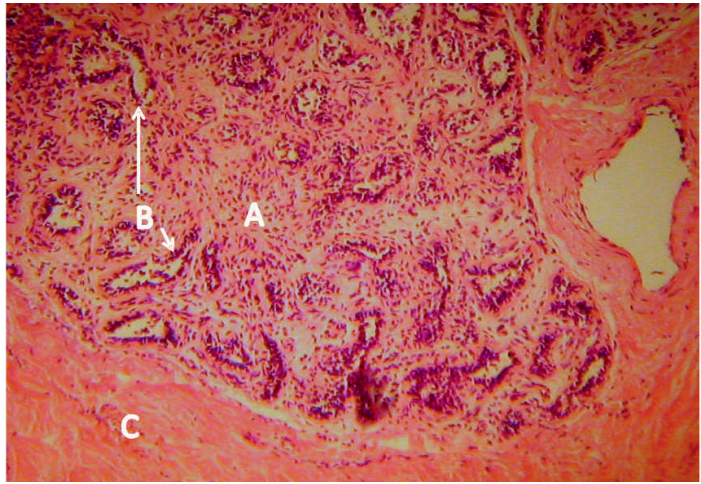

b)

Figure 2a-b. Acinar atrophy of the mammary gland (A, B) with proliferation of connective tissue (C)

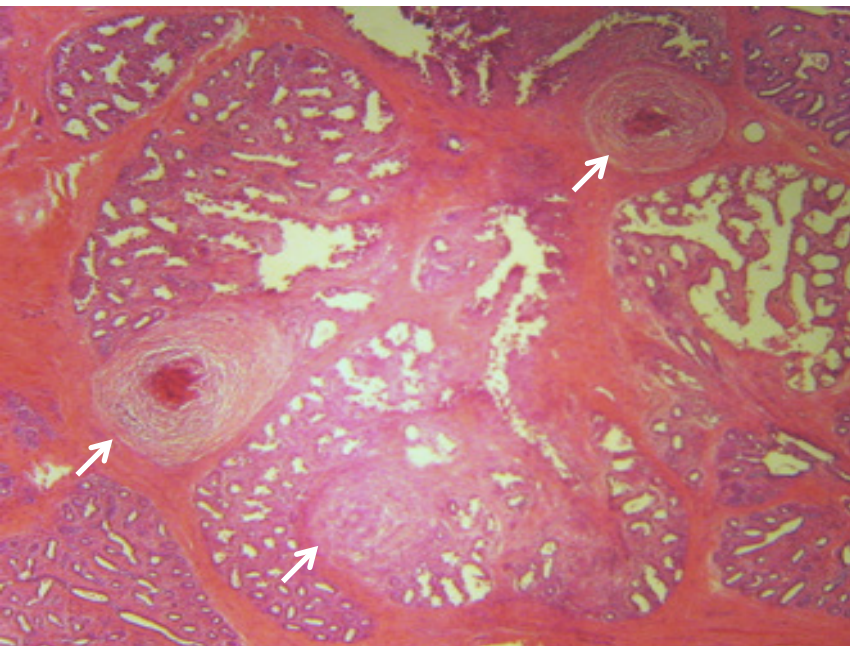

Figure 3. Granulomatous inflammation process in udder parenchyma (arrow) 
Table 3. Milk production, SCC and milk selenium concentration in cows with optimal and suboptimal selenium concentrations

\begin{tabular}{lccc}
\hline & Blood Se optimal & Blood Se suboptimal & $\mathrm{p}$ \\
\hline Milk production & 25.4 & 24.5 & NS \\
\hline SCC first month $(000 / \mathrm{mL})$ & $341 \pm 66$ & $432 \pm 73$ & $<0.01$ \\
\hline SCC sixth month $(000 / \mathrm{mL})$ & $251 \pm 51$ & $325 \pm 55$ & $<0.01$ \\
\hline Milk Se & $0.07 \pm 0.004$ & $0.12 \pm 0.004$ & $<0.01$ \\
\hline
\end{tabular}

Table 4. Test of trend - changes in the proportion of udder quarters with varying degrees of parenchymal infiltration and varying intensity of inflammation processes in cows with optimal and suboptimal (deficient) blood selenium concentrations

\begin{tabular}{|c|c|c|c|c|c|}
\hline \multirow[b]{2}{*}{ Histological finding } & & \multicolumn{3}{|c|}{ Udder quarters } & \multirow[b]{2}{*}{$\mathrm{p}$} \\
\hline & & $\begin{array}{c}\text { Blood Se optimal } \\
\text { n (\%) }\end{array}$ & $\begin{array}{c}\text { Blood Se } \\
\text { suboptimal } \\
\text { n (\%) }\end{array}$ & $\begin{array}{l}\text { Total } \\
\text { n (\%) }\end{array}$ & \\
\hline \multirow{4}{*}{$\begin{array}{l}\text { Leukocyte infiltration } \\
\qquad \%\end{array}$} & $0-25 \%$ & $36(80)$ & $9(20)$ & $45(100)$ & \multirow{4}{*}{$<0.01$} \\
\hline & $25.1-50 \%$ & $24(68.6)$ & $11(31.4)$ & $35(100)$ & \\
\hline & $50.1-75 \%$ & $16(57.1)$ & $12(42.9)$ & $28(100)$ & \\
\hline & $75.1-100 \%$ & $0(0)$ & $12(100)$ & $12(100)$ & \\
\hline \multirow{4}{*}{ Number of granulomas } & 0 & $13(92.9)$ & $1(7.1)$ & $14(100)$ & \multirow{4}{*}{$<0.01$} \\
\hline & $1-3$ & $45(78.9)$ & $12(21.1)$ & $57(100)$ & \\
\hline & $4-5$ & $15(50)$ & $15(50)$ & $30(100)$ & \\
\hline & $>5$ & $3(15.8)$ & $16(84.2)$ & $19(100)$ & \\
\hline
\end{tabular}

Also, no significant relationship was observed between blood selenium concentration and the amount of milk produced. Selenium concentration in milk negatively correlated with milk somatic cell count in early and mid lactation, and no relationship was established with the amount of milk produced. The results are given in Table 2 .

The classification of cows based on blood selenium concentration gave results which suggested that selenium-deficient cows had a significantly higher somatic cell count in early (the first month) and mid lactation (the sixth month) and a significantly lower milk selenium concentration compared to the cows exhibiting optimal selenium concentrations (Table 3).

Samples of individual udder quarters were classified according to the degree of leukocyte infiltra- tion and number of granulomas. The results showed that an increase in the degree (percent) of leukocyte infiltration and number of granulomas in the tested quarter tissues increases the number (percentage) of quarters from selenium-deficient cows and significantly decreases the number (percentage) of quarters obtained from cows with normal concentrations of selenium in the blood (Table 4).

The range of physiological values for blood selenium in dairy cows is 0.6 to $0.9 \mathrm{mmol} / \mathrm{L}$ (Erdeljan et al. 2011; Juniper et al., 2006, Gunter et al., 2003). Selenium concentration in the milk from cows receiving sufficient dietary selenium is between 0.117 and $0.2 \mathrm{mmol} / \mathrm{L}$ (Ceballos et al., 2009). Pechová et al. (2008) reported that there is no significant correlation between blood selenium concentration and milk selenium concentration, which is consistent with our results. However, Grace et 
al. (2001) found a statistically significant linear correlation between blood selenium concentration and milk selenium. The concentration of selenium in the blood and breast milk depends on selenium supplements used on farms, since the use of selenium leads to a significant increase in its concentration in the blood and breast milk (Ran et al., 2010).

Atroshi et al. (1986) and Hogan et al. (1993) found that the occurrence of mastitis in cows is associated with low glutathione peroxidase and vitamin E in the blood plasma. Kruse et al. (2007) observed that cows infected with Staphylococcus aureus receiving selenium in their diet showed a significantly higher glutathione peroxidase activity and a significantly lower milk somatic cell count. Low levels of glutathione peroxidase were found to reduce the antioxidant capacity of the defense system of the mammary gland, leading to an increase in mastitis incidence and somatic cell count in milk (Mukherjee, 2008). Selenium concentrations and glutathione peroxidase activity are positively correlated (Pilarczyk et al., 2012). Selenium is an integral part of the enzyme, and this can explain why selenium-deficient cows exhibit higher infiltration of inflammatory cells undergoing excessive inflammation. Selenium deficiency provokes an inflammatory process due to reduced antioxidant activity in tissues when there is an accumulation of immune cells in response to prolonged inflammation; therefore, the concentration of selenium negatively correlated with the degree of cellular infiltration in the parenchyma of the udder. A reduction in mastitis after dietary selenium and vitamin $\mathrm{E}$ intakes occurs as a result of enhanced activities of glutathione peroxidase (Hemmingway, 1999; Weiss et al., 1997). Selenium supplementation leads to a reduction in subclinical mastitis and somatic cell count in dairy cows (Barbano et al., 2006; Cope et al., 2009; Rabiei et al., 2010; Weiss et al., 2002; Davidov et al., 2012).

The effect of selenium on milk somatic cell count and histological characteristics of the udder can be explained as follows. Bacterial infection and growth in the mammary gland is the main etiological factor of mastitis (Mukherjee, 2008). As a result of bacterial penetration leading to the breakdown of the blood-milk barrier, neutrophilic granulocytes from the blood come to the site of infection (Zhao and Lacasse, 2008). These cells provide the first line of defense against invading bacteria i.e. phagocytosis and killing of bacteria. After phagocytosis, these cells release large amounts of cytotoxic free radicals and pro-inflammatory cytokine in order to destroy fagocytized bacteria (Knaapen et al., 1999). Inflammatory substances resulting from the release of highly reactive molecules mitigate antioxidants which are intracellular defense mechanisms against oxidation. Superoxide dismutase, glutathione peroxidase and catalase in the mammary cells remove superoxide and peroxides before they react with the metal catalyst and create compounds that are destructive and toxic to cells. This intracellular defense mechanism leads to damage of the mammary gland during the acute phase of inflammation (Ndiveni et al., 1991; Fuchs and Milbradt, 1994).

Histological findings of this experiment indicate characteristic signs of inflammatory processes including edema, epithelial damage of secretory parenchyma cells, different degrees of leukocyte infiltration and the occurrence of inflammation processes (granulomas and fibrosis of the connective septa) (Jovanović et al., 2012). Benites et al. (2002) histologically examined 184 parenchyma of the udder and performed microbiological isolation from the udders of cows excluded from milk production. Inflammation was found in $96.9 \%$ of tissue samples, from which agents were isolated No histological change was detected in $3.1 \%$ of the samples. Histological changes were similar to those found in this study. Our results are in accordance with the above findings since signs of inflammation processes were detected in practically all udder quarters.

\section{Conclusion}

Blood selenium concentration plays an important role in maintaining mammary gland health. Selenium-deficient cows were found to have a large milk somatic cell count and exhibit inflammatory (stronger immune infiltration of the parenchyma cells) and inflammation processes (acinar atrophy, proliferation of the connective tissue and granuloma formation) in the parenchyma of the mammary gland. Changes caused by selenium deficiency in the udder of cows are due to the marked inflammation of the mammary gland tissue. 


\section{Acknowledgments}

This research is part of Projects Ref. Nos. TR31062 and TR31095 funded by the Ministry of Education, Science and Technological Development, Republic of Serbia.

\section{Utjecaj selena u krvnom serumu na zdravstvene karakteristike vimena krava}

\section{Sažetak}

Cilj rada bio je istražiti utjecaj koncentracije selena u ranoj laktaciji na zdravlje mliječne žlijezde i histološke karakteristike vimena krava. U istraživanje je bilo uključeno 30 visokomliječnih krava holštajn-frizijske pasmine. Analizirana je koncentracija selena u krvnom i mliječnom serumu, kao i prosječan broj somatskih stanica u prvom i šestom mjesecu laktacije. Nakon isključenja krava iz proizvodnje istraživana su histološka svojstva vimena krava (stupanj leukocitne infiltracije i broj granuloma $u$ parenhimu). Prosječna koncentracija selena $u$ krvnom serumu krava iznosila je 0,62 $\pm 0,11 \mu \mathrm{mol} / \mathrm{L}$, a u mliječnom $0,12 \pm 0,07 \mu \mathrm{mol} / \mathrm{L}$. U ogledu je utvrđeno 19 krava s optimalnom koncentracijom selena u krvi i 11 sa suboptimalnom koncentracijom. Utvrđena je značajna negativna korelacija koncentracije selena u krvi i mlijeku s brojem somatskih stanica u ranoj i srednjoj laktaciji. Nije utvrđena veza između koncentracije selena $\mathrm{u}$ krvi s koncentracijom selena u mlijeku i količinom proizvedenog mlijeka. Krave koje su deficitarne u selenu imaju značajno veći broj somatskih stanica u mlijeku u ranoj i srednjoj laktaciji i značajno nižu koncentraciju selena u mlijeku. Kada se nakon histološke analize 120 uzoraka pojedinačnih četvrti vimena grupiraju prema stupnju leukocitne infiltracije, odnosno prema broju granuloma, može se zaključiti da s porastom stupnja leukocitne infiltracije, odnosno broja granuloma u tkivu, raste udio onih četvrti koje potječu od krava deficitarnih u selenu, dok opada udio četvrti koje potječu od krava s normalnom koncentracijom selena u krvi. Selen značajno utječe na zdravlje vimena, a promjene koje izaziva deficit selena nastaju kao posljedica izražene inflamacije i reparacije u tkivu mliječne žlijezde.

Ključne riječi: krave, selen, histologija vimena, upala

\section{References}

1. Atroshi, F., Parantainen, J., Sankari, S., Osterman, T. (1986): Prostaglandin and glutathione peroxidase in bovine mastitis. Res Vet Sci 40, 361-366.

2. Barbano, D.M., Ma, Y., Santos, M.V. (2006): Influence of raw milk quality on fluid milk shelf life. J Dairy Sci $89,15-19$

doi: dx.doi.org/10.3168/jds.S0022-0302(06)72360-8

3. Benites, N.R., Guerra, J.L., Melville, P.A., da Costa, E.O. (2002): Aetiology and histopathology of bovine mastitis of a spontaneous occurrence. J Vet Med B49, 366-370. doi: dx.doi.org/10.1046/j.1439-0450.2002.00566.x

4. Ceballos, A., Sánchez, J., Stryhn, H., Montgomery, J.B., Barkema, H.W., Wichtel, J.J. (2009): Meta analysis of the effect of oral selenium supplementation on milk selenium concentration in cattle. J Dairy Sci 92, 324-342. doi: dx.doi.org/10.3168/jds.2008-1545

5. Cope, C.M., Mackenzie, A.M., Wilde, D., Sinclair, L.A. (2009): Effects of level and form of dietary zinc on dairy cow performance and health. J Dairy Sci 92, 2128-2135. doi: dx.doi.org/10.3168/jds.2008-1232

6. Davidov, I., Radinović, M., Erdeljan, M., Belić, B., Cincović, M.R., Boboš, S. (2012): Blood selenium concentration, somatic cell count and their correlation at first and sixth month of lactation in dairy cows. Contemporary Agriculture 61 (1-2), 95-103.

7. Davidov, I., Radinović, M., Erdeljan, M., Cincović, M.R., Stančić, I., Belić, B. (2013): Relations between blood Zinc concentrations and udder health in dairy cows. Rev Méd Vét 164 (4), 183-190.

8. Erdeljan, M., Davidov, I., Boboš, S., Radinović, M., Stančić, I. (2011): Nalaz nivoa selena u krvnom serumu kod krava u laktaciji. Letopis naučnih radova Poljoprivrednog fakulteta u Novom Sadu 35 (1), 104-109.

9. Finch, J.M., Turner, R.J. (1996): Effects of selenium and vitamin $\mathrm{E}$ on the immune response of domestic animals. Res Vet Sci 60, 97-106. doi: dx.doi.org/10.1016/S0034-5288(96)90001-6

10. Fuchs, J., Milbradt, R. (1994): Antioxidant inhibition of skin inflammation induced by reactive oxidants: evaluation of the redox couple dihydrolipoate/lipoate. Skin Pharma 7, 278-84. doi: dx.doi.org/10.1159/000211306

11. Grace, N.D., Ankenbauer-Perkins, K.L., Alexander, A.M., Marchant, R.M. (2001): Relationship between blood selenium concentration or glutathione peroxidase activity, and milk selenium concentrations in New Zealand dairy cows. NZ Vet J 49 (1), 24-28. doi: dx.doi.org/10.1080/00480169.2001.36198

12. Gunter, S.A., Beck, P.A., Phillips, J.M. (2003): Effects of supplementary selenium source on the performance and blood measurements in beef cows and their calves. $J$ Anim Sci 81, 856-864.

13. Hemmingway, R.G. (1999): The influences of dietary selenium and vitamin $\mathrm{E}$ intakes on milk defense responses to mastitis. J Dairy Sci 76, 2795-2803. 
14. Hogan, J.S., Weiss, W.P., Smith, K.L. (1993): Role of vitamin $\mathrm{E}$ and selenium in host defense against mastitis. J Dairy Sci 76, 2795-2803. doi: dx.doi.org/10.3168/jds.S0022-0302(93)77618-3

15. Jovanović, M., Aleksić-Kovačević, S., Knežević, M. (2012): Specijalna veterinarska patologija, Fakultet veterinarske medicine Beograd, 245-248.

16. Juniper, D.T., Phipps, R.H., Jones, A.K., Betrin, G. (2006): Selenium supplementation of lactating dairy cows: effect on selenium concentration in blood, milk, urine and feces. J Dairy Sci 89, 3544-3551. doi: dx.doi.org/10.3168/jds.S0022-0302(06)72394-3

17. Knaapen, A.M., Nehls, P., Borm, A.J. (1999): Neutrophils cause oxidative DNA damage in alveolar epithelial cells. Free Rad Bio Med 27, 234-240. doi: dx.doi.org/10.1016/S0891-5849(98)00285-8

18. Kommisrud, E., Osteras, O., Vatn, T. (2005): Blood selenium associated with health and fertility in Norwegian dairy herds. Acta Vet Scand 46, 229-240. doi: dx.doi.org/10.1186/1751-0147-46-229

19. Kruze, J., Ceballos, A., Stryhn, H., Mella, A., Matamoros, R., Contreras, P.A., Leyan, V., Wittwer, F. (2007): Somatic cell count in milk of selenium-supplemented dairy cows after an intramammary challenge with Staphylococcus aureus. J Vet Med A Physiol Pathol Clin Med. 54 (9), 478-483. doi: dx.doi.org/10.1111/j.1439-0442.2007.00999.x

20. Larsen, H.J.S. (1993): Relation between selenium and immunity. Nor J Agric Sci 11,105-119.

21. Malard, B.A., Dekkers, J.C., Ireland, J.M., Leslie, K.E., Sharif, S., Lacey, V.C., Wacter, L., Wilkie, B.N. (1998): Alteration in immune responsiveness during the peripartum period and its ramification on dairy cow and calf health. J Dairy Sci 81, 585-595. doi: dx.doi.org/10.3168/jds.S0022-0302(98)75612-7

22. Mayer, G., Klein, M. (1961): Histology and cytology of the mammary gland, U Kon SK, Cowie AT, editors. Milk: the mammary gland and its secretion (Vol. 1). New York: Academic Press.

23. McKenzie, R.C., Rafferty, T.S., Beckett, G.J. (1998): Selenium: an essential element for immune function. Immunol Today 19, 342-345. doi: dx.doi.org/10.1016/S0167-5699(98)01294-8

24. Miller, G.Y., Bartlett, P.C., Erskine, R.J., Smith, K.L. (1995): Factors affecting serum selenium and vitamin $\mathrm{E}$ concentration in dairy cows. JAVMA 206, 1369-1373.

25. Miller, J.K., Brzezinska-Slebodzinska, E., Madsen, F.C. (1993): Oxidative stress, antioxidants and animal function. J Dairy Sci 76, 2812-2823. doi: dx.doi.org/10.3168/jds.S0022-0302(93)77620-1

26. Mukherjee, R. (2008): Selenium and vitamin E increases polymorphonuclear cell phagocytosis and antioxidant levels during acute mastitis in riverine buffaloes. Vet Res Commun 32, 305-313. doi: dx.doi.org/10.1007/s1 1259-007-9031-9
27. Ndiveni, N., Field, T.R., Williams, M.R., Booth, J.M. (1991): Studies on the incidence of clinical mastitis and blood levels of vitamin $\mathrm{E}$ and selenium in dairy herds in England. Vet Rec 129, 86-88. doi: dx.doi.org/10.1136/vr.129.5.86

28. Pechová, A., Pavlata, L., Dvorák, R., Lajková, E. (2008): Contents of $\mathrm{Zn}, \mathrm{Cu}, \mathrm{Mn}$ and Se in Milk in Relation to their Concentrations in Blood, Milk Yield and Stage of Lactation in Dairy Cattle. Acta Vet Brno 77, 523-531. doi: dx.doi.org/10.2754/avb200877040523

29. Pilarczyk, B., Jankowiak, D., Tomza-Marciniak, A., Pilarczyk, R., Sablik, P., Drozd, R., Tylkowska, A., Skólmowska, M. (2012): Selen um concentration and glutathione peroxidase (GSH-Px) activity in serum of cows at different stages of lactation. Biol Trace Elem Res 147 (1-3), 91-96. doi: dx.doi.org/10.1007/s12011-011-9271-y

30. Rabiee, A.R., Lean, I.J., Stevenson, M.A., Socha, M.T. (2010): Effects of feeding organic trace minerals on milk production and reproductive performance in lactating dairy cows: A meta-analysis. J Dairy Sci 93, 4239-4251. doi: dx.doi.org/10.3168/jds.2010-3058

31. Ran, L., Wu, X., Shen, X., Zhang, K., Ren, F., Huang, K. (2010): Effects of selenium form on blood and milk selenium concentrations, milk component and milk fatty acid composition in dairy cows. J Sci Food Agric 90 (13), 2214-2219. doi: dx.doi.org/10.1002/jsfa.4073

32. Smith, K.L., Hogan, J.S., Weiss, W.P. (1997): Dietary vitamin $\mathrm{E}$ and selenium affect mastitis and milk quality. $J$ Anim Sci 75, 1659-1665.

33. Sordillo, L.M., Shafer-Weaver, K., DeRosa, D. (1997): Immunobiology of the mammary gland. J Dairy Sci 80, 1851-1865. doi: dx.doi.org/10.3168/jds.S0022-0302(97)76121-6

34. Weiss, W.P., Hogan, J.S., Todhunter, D.A., Smith, K.L. (1997): Effect of vitamin E supplementation in diets with a low concentration of selenium on mammary gland health of dairy cows. J Dairy Sci 80, 1728-1737. doi: dx.doi.org/10.3168/jds.S0022-0302(97)76105-8

35. Weiss, W.P. (2002): Relationship of mineral and vitamin supplementation with mastitis and milk quality. In: Proc. Annual Meeting, National Mastitis Concil, Orlando, Florida, USA, 37-44.

36. Zhao, X., Lacasse, P. (2008): Mammary tissue damage during bovine mastitis: Causes and control. J Anim Sci $86,57-65$.

doi: dx.doi.org/10.2527/jas.2007-0302 